\title{
Skład osobowy prawosławnego domu zakonnego pw. św. Antoniego Pieczerskiego w Radecznicy w latach 1881 - 1899
}

\author{
Stefan Dmitruk \\ dmitruk.stefan@gmail.com
}

\begin{abstract}
Stefan Dmitruk, Members of Saint Anthony Pieczerski's Orthodox Monastery in Radecznica from 1881 to 1889, Elpis, 162014 : 183-190.

Abstract: The author discusses questions related to the members of the Orthodox Monastery in Radecznica at the end of the $19^{\text {th }}$ century. Archival materials, press information and essays were analysed and used to reach final conclusions regarding the mentioned group of monks. The author answers questions related to geographical, social, national origins of the monks, as well as their age and education. The author attempts to establish a view of the development of the men's monastery in Radecznica.
\end{abstract}

\begin{abstract}
Streszczenie: Autor omawia zagadnienie związane z obsadą personalną prawosławnego domu zakonnego w Radecznicy w końcu XIX w. Analiza źródeł archiwalnych, informacji prasowych oraz opracowań posłużyła do ustalenia wniosków końcowych związanych z omawianą grupą badawczą. Autor odpowiada na pytania związane z pochodzeniem geograficznym, społecznym, narodowością, wiekiem, wykształceniem mnichów i próbuje określić perspektywę rozwoju męskiego domu zakonnego w Radecznicy.
\end{abstract}

Słowa kluczowe: Radecznica, monaster, mnisi prawosławni, św. Antoni Pieczerski, diecezja chełmsko-warszawska

Keywords: Radecznica, monastery, orthodox monks, Saint Anthony Pieczerski, diocese in Chełm and Warsaw

Krótkie dzieje (lata 1881 - 1915) prawosławnego monastycyzmu w Radecznicy w dalszym ciągu pozostają niewystarczająco zbadane i czekają na opracowanie. Zagadnienie to poruszono w publikacjach: Stanisława Rapy, Urszuli Pawluczuk, Reginy Smoter-Grześkiewicz, Krzysztofa Latawca i Stefana Dmitruka ${ }^{1}$. Prace dwóch ostatnich wymienionych autorów są oparte na licznych materiałach archiwalnych. W efekcie wnoszą nowe, nieznane ustalenia do dyskursu historycznego związanego z prawosławnym monastycyzmem na ziemiach polskich na przełomie XIX i XX w.

Celem tekstu jest zarysowanie biogramów mnichów, zamieszkujących męski dom zakonny w Radecznicy między 1881 a 1899 r. z pominięciem informacji na temat form ich działania. Daty graniczne wyznaczają okres funkcjonowania męskiej wspólnoty zakonnej, która powstała 29 grudnia $1881 \mathrm{r}^{2} \mathrm{Z}$ dniem 7 stycznia $1899 \mathrm{r}$. męski dom zakonny w Radecznicy przekształcono w monaster żeński ${ }^{3}$. Bazę źródłową do omawianego tematu stanowią akta przechowywane w Archiwum Państwowym w Lublinie (dalej:

\footnotetext{
K. Latawiec, $W$ slużbie imperium...Struktura społeczno-zawodowa ludności rosyjskiej na terenie guberni rosyjskiej w latach 1864 - 1915, Lublin 2007, s. 221 - 225; U. Pawluczuk, Życie monastyczne w II Rzeczypospolitej, Białystok 2007, s. 37 - 38; tejże, Ośrodki monastyczne w XIX w. na terenach Rzeczypospolitej, [w:] „Pokazanie Cerkwie prawdziwej...”. Studia nad dziejami i kultura Kościoła prawosławnego w Rzeczypospolitej, Białystok 2004, s. 157 - 158; S. Rapa, Ośrodek kultu religijnego w Radecznicy w latach 1772 - 1914, [w:] Radecznica. Ośrodek życia religijnego i społecznokulturalnego, red. R. Jusiak, Kalwaria Zebrzydowska 2006, s. 136 - 141; Dzieje gminy Radecznica, red. R. Smoter-Grześkiewicz, Zamość 2006, s. 137 - 139; S. Dmitruk, Żeńskie monastery prawosławne na terenie Królestwa Polskiego na przełomie XIX i XX w., „,Teka Komisji Historycznej. Oddział PAN w Lublinie", t. VI, Lublin 2009, s. 75 - 78.

2 Daty dzienne są podawane zgodnie z kalendarzem juliańskim.

3 S. Dmitruk, Żeńskie monastery..., s. 76 - 77.
}

APL). Kwerenda archiwalna objęła zespoły: Chełmsko -Warszawski Duchowny Konsystorz Prawosławny (1875 - 1905; dalej: ChWDKP), Chełmski Zarząd Duchowny ([1848] 1875-1905; dalej: ChZD), Chełmski Konsystorz Prawosławny (1905 - 1918; dalej: ChKP) oraz Chełmski Konsystorz Greckokatolicki [1525-1595] 1596-1875 [18761905; dalej: ChKG]. Pożądanego rezultatu nie przyniosła kwerenda przeprowadzona $\mathrm{w}$ „Klirowych Wiedomostiach” (dalej: KW) należących do zespołu ChKP ${ }^{4}$. Braki w dokumentacji związanej z poruszanym zagadnieniem powodują wybiórczość informacji, tym niemniej umożliwiają przeprowadzenie prawidłowej analizy oraz wyciągnięcie wniosków. W przedstawionym badaniu posiłkowano się kwerendą prasową, przeprowadzoną w Bibliotece Katolickiego Uniwersytetu Lubelskiego im. Jana Pawła II w Lublinie (analiza treści czasopism „Chołmskoj Cerkownoj Żyzni” [dalej: ChCŻ], „Chołmsko-Warszawski Jeparchialny Wiestnik” [dalej: ChWJW], „Pamiatnaja Kniżka Lublinskoj Gubierni” [dalej: PKLG] oraz „Warszawskij Dniewnik”). $\mathrm{W}$ ustaleniu biogramów było pomocne opracowanie autorstwa ks. Grzegorza Sosny i Antoniny Troc-Sosny ${ }^{5}$.

Parafia prawosławna w Radecznicy z powodu małej liczby wiernych (w $1881 \mathrm{r}$. liczyła 147 osób $^{6}$ ) była nierentowną jednostką administracyjną, funkcjonującą w ramach de-

\footnotetext{
4 Negatywny efekt kwerendy wynika $\mathrm{z}$ likwidacji parafii prawosławnej w Radecznicy w $1881 \mathrm{r}$. W związku z tym nie ma kompletu KW z Radecznicy za lata 1881 - 1899 w ChZD. W toku kwerendy okazało się, że jedynie w latach 1885 - 1887 zostały wytworzone takie akta. Znajdują się one w APL w ChZD (sygn. 1031). Nie udało się odnaleźć podobnych dokumentów za lata $1888-1899$.

5 G. Sosna, A. Troc-Sosna, Hierarchia i kler Kościoła Prawosławnego w granicach II Rzeczypospolitej i Polski powojennej w XIX - XXI wieku, Ryboły 2012.

6 APL, KW, sygn. 1010, k. 52 v.; APL, ChKG, sygn. 441, k. 277.
} 
kanatu zamojskiego diecezji chełmsko-warszawskiej Rosyjskiej Cerkwi Prawosławnej (dalej: RCP). W związku z tym cerkiew radecznicka utraciła status parafialnej ${ }^{7}$. W połowie marca 1881 r. bp lubelski Modest (Strelbicki; ur. 1823, zm. 1902) poinformował Konsystorz Diecezji Chełmsko-Warszawskiej, iż na obszarze eparchii nie ma żadnego monasteru, który mógłby prowadzić działania misyjne wśród ludności pounickiej, zaś w samym dekanacie zamojskim duchowieństwo osiągnęło nikłe efekty wymienionej działalności. Podobna sytuacja miała miejsce nieopodal Białej Podlaskiej ${ }^{8}$. Hierarcha stwierdził, że na wspomnianych terenach wystąpiły konwersje wiernych z prawosławia na rzymski katolicyzm po kasacie unii brzeskiej w 1875 r. ${ }^{9}$ Jednocześnie władyka podkreślał, iż okoliczni mieszkańcy kontynuują tradycje pątnicze (święto ku czci św. Antoniego z Padwy) związane z funkcjonującym od XVII w. w Radecznicy klasztorem bernardyńskim ${ }^{10}$. W związku z tym pojawiła się okazja do zastąpienia kultu św. Antoniego z Padwy (patron byłego klasztoru bernardyńskiego) kultem św. Antoniego Pieczerskiego oraz zintensyfikowaniem lokalnej, prawosławnej działalności misyjnej (uruchomienie placówek oświatowych, utworzenie chóru cerkiewnego itp. ${ }^{11}$. Te czynniki legły u podstaw powołania do życia wspólnoty zakonnej przy Domu Biskupim w Chełmie, utworzeniu jego filii w Radecznicy oraz zaplanowaniu przez władze diecezjalne uruchomienia żeńskiego monasteru w Leśnej Podlaskiej ${ }^{12}$.

Ustalono etaty filii w Radecznicy na dwóch hieromnichów, którzy mieli otrzymywać roczne pensje po 150 rubli (dalej: rb.), hierodiakona (120 rb.), trzech nowicjuszy (60 rb.) oraz stróża cerkiewnego $(150 \mathrm{rb} \text {. })^{13} .29$ grudnia $1881 \mathrm{r}$. bp Modest zdecydował o uruchomieniu $\mathrm{z}$ dniem 15 stycznia 1882 r. męskiego domu zakonnego w Radecznicy ${ }^{14}$. Po zakończonym remoncie, podczas święta parafialnego 1 czerwca 1882 r., dokonał on uroczystego poświęcenia cerkwi oraz obwieścił uruchomienie monasteru w Radecznicy. ${ }^{15}$ Świątobliwy Synod RCP dopiero 25 grudnia 1884 r. zatwierdził zmianę statusu parafii w Radecznicy na cerkiew filialną Domu Biskupiego w Chełmie ${ }^{16}$. „Reguly monasteru w Radecznicy" zatwierdził 10 sierpnia 1882 r. władyka Modest ${ }^{17}$.

Problemy ekonomiczne, o których w końcu października 1898 r. informował władze diecezjalne ówczesny przełożony Pimen (Gorbunow), były podstawą do przekształcenia męskiego domu zakonnego w żeński monaster I klasy. Stało się to dzięki decyzji Świątobliwego Synodu z 7 stycznia 1899 r. Pod koniec stycznia bp lubelski Herman (Iwanow; ur. 1863, zm. 1903), przełożoną żeńskiego monasteru w Radecznicy mianował mniszkę Anastazję

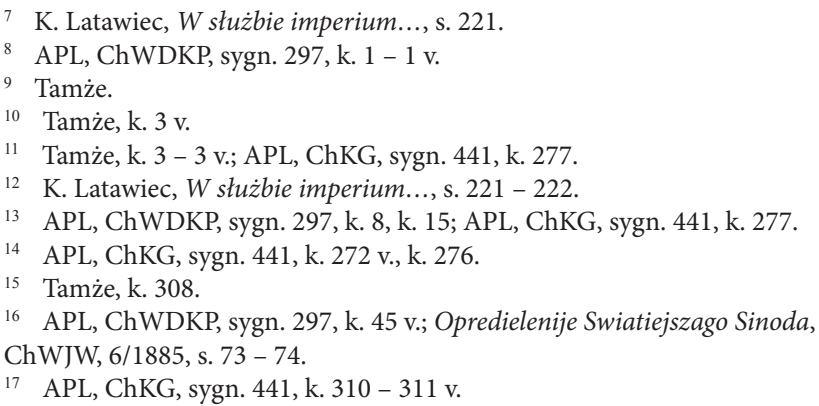

(Gromiekę), która wcześniej niosła posługę w monasterze w Leśnej Podlaskiej ${ }^{18}$. Według K. Latawca, mnisi przebywający w męskim domu zakonnym w Radecznicy, zostali przeniesieni do Jabłecznej ${ }^{19}$.

W ciągu 17 lat funkcjonowania męskiego monastycyzmu w Radecznicy niosło w nim posługę 14 osób (zob. Tab. 1). W tej grupie było: siedmiu hieromnichów (z tego czterech przełożonych; 50, $00 \%$ składu), dwóch hierodiakonów $(14,28 \%)$, jeden mnich $(7,14 \%)$ i czterech nowicjuszy $(28,57 \%)$.

\section{Tab. 1. Mnisi w monasterze w Radecznicy w okresie między 1882 a 1899 r. $^{20}$}

\begin{tabular}{|c|c|c|c|c|}
\hline \multirow{2}{*}{ LP } & \multirow{2}{*}{$\begin{array}{l}\text { Tytuł mniszy, imię } \\
\text { i nazwisko }\end{array}$} & \multirow{2}{*}{ Funkcja } & \multicolumn{2}{|c|}{ Pobyt w Radecznicy } \\
\hline & & & początek & koniec \\
\hline 1 & $\begin{array}{l}\text { hieromnich Hipacy } \\
\text { (brak nazwiska) }\end{array}$ & przełożony & $\begin{array}{l}15 \text { stycznia } \\
1882 \mathrm{r} .\end{array}$ & b. d. \\
\hline 2 & $\begin{array}{l}\text { hieromnich Antoni } \\
\text { (Dziuba) }\end{array}$ & przełożony & $\begin{array}{c}21 \text { września } \\
1883 \mathrm{r} \text {. }\end{array}$ & $\begin{array}{c}13 \text { września } \\
1891 \mathrm{r} .\end{array}$ \\
\hline 3 & $\begin{array}{l}\text { hieromnich Krzysztof } \\
\text { (Sakowicz) }\end{array}$ & przełożony & $\begin{array}{c}16 \text { września } \\
1891 \mathrm{r} .\end{array}$ & $\begin{array}{c}15 \text { lutego } \\
1897 \mathrm{r} \text {. }\end{array}$ \\
\hline 4 & $\begin{array}{l}\text { hieromnich Pimen } \\
\text { (Gorbunow) }\end{array}$ & przełożony & $\begin{array}{c}1889 \text { r. (przeło- } \\
\text { żony od lutego? } \\
1897 \text { r.) }\end{array}$ & $\begin{array}{c}27 \text { września } \\
1898 \mathrm{r} .\end{array}$ \\
\hline 5 & $\begin{array}{c}\text { hieromnich Innocenty } \\
\text { (Tryszczuk) }\end{array}$ & $\begin{array}{l}\text { mnich-ka- } \\
\text { płan }\end{array}$ & $\begin{array}{c}15 \text { stycznia } \\
1883 \mathrm{r} .\end{array}$ & 1890 \\
\hline 6 & $\begin{array}{l}\text { hieromnich Doroteusz } \\
\text { (brak nazwiska) }\end{array}$ & $\begin{array}{l}\text { mnich-ka- } \\
\text { płan }\end{array}$ & $\begin{array}{c}15 \text { sierpnia } \\
1890 \mathrm{r} .\end{array}$ & b. d. \\
\hline 7 & $\begin{array}{c}\text { hieromnich Onufry } \\
\text { (Skibiński) }\end{array}$ & $\begin{array}{l}\text { mnich-ka- } \\
\text { płan }\end{array}$ & $1890 \mathrm{r}$. & $1895 \mathrm{r}$. \\
\hline 8 & $\begin{array}{c}\text { hierodiakon Antoni } \\
\text { (Miroszniczenko) }\end{array}$ & $\begin{array}{l}\text { mnich-dia- } \\
\text { kon }\end{array}$ & 3 maja $1882 \mathrm{r}$. & $\begin{array}{l}1 \text { lipca } \\
1882 \text { r. }\end{array}$ \\
\hline 9 & $\begin{array}{l}\text { hierodiakon Serapion } \\
\text { (Milniewicz) }\end{array}$ & $\begin{array}{l}\text { mnich-dia- } \\
\text { kon }\end{array}$ & $\begin{array}{c}18 \text { stycznia } \\
1893 \mathrm{r} .\end{array}$ & $\begin{array}{c}\text { grudzień } \\
1895 \mathrm{r} .\end{array}$ \\
\hline 10 & $\begin{array}{c}\text { mnich Antoni } \\
\text { (Jaroszuk) }\end{array}$ & mnich & $\begin{array}{c}1 \text { kwietnia } \\
1897 \mathrm{r} \text {. }\end{array}$ & b. d. \\
\hline 11 & Mikołaj (Simoniuk) & nowicjusz & $\begin{array}{c}20 \text { kwietnia } \\
1887 \mathrm{r} \text {. }\end{array}$ & b. d. \\
\hline 12 & Piotr (Bystrymowicz) & nowicjusz & $\begin{array}{c}7 \text { października } \\
1886 \mathrm{r} .\end{array}$ & b. d. \\
\hline 13 & Antoni (Łukaszewicz) & nowicjusz & $\begin{array}{l}2 \text { grudnia } \\
1885 \mathrm{r} \text {. }\end{array}$ & b. d. \\
\hline 14 & Cyprian (Jankowski) & nowicjusz & $\begin{array}{c}20 \text { grudnia } \\
1885 \mathrm{r} \text {. }\end{array}$ & b. d. \\
\hline
\end{tabular}

Spróbujmy przyjrzeć się szczegółom biografii mnichów zamieszkujących radecznicki monaster. Pierwszym przełożonym był nieznany z nazwiska hieromnich Hipacy. Ignacy $^{21}$ urodził się $1833 \mathrm{r}$. w Kijowie w rodzinie mieszczańskiej. 11 września $1861 \mathrm{r}$. rozpoczął nowicjat w jednym

\footnotetext{
8 Tamże, k. 340 i 347; Naznaczenija, ChWJW, 6/1899, s. 6; K. Latawiec, W stużbie imperium..., s. 223.

19 K. Latawiec, W stużbie imperium..., s. 223.

20 Tab. na podst.: APL, ChZD, sygn. 1031 (cały poszyt); APL, ChZD, sygn. 1258, k. 1 - 10; APL, ChZD, sygn. 1365, k. 1 - 16; APL, ChZD, sygn. 1705 (cały poszyt); APL, ChZD, sygn. 1905, k. $1-3$ v.; APL, ChWDKP, sygn. 239, k. 1 - 2; APL, ChKP, sygn. 49, k. 2 v. - 3 v.; PKLG na 1887 god, b. m. w., s. 80; PKLG na 1888 god, b. m. w., s. 81; PKLG na 1890 god, Lublin 1890, s. 240; PKLG na 1893 god, Ljublin 1892, s. 245; PKLG na 1895 god, Ljublin 1894, s. 252; G. Sosna, A. Troc-Sosna, Hierarchia i kler..., s. 74, s. 151, s. 212 , s. 304 , s. 309 , s. 474 , s. 679 ; K. Latawiec, $W$ stużbie imperium..., s. 222-225. Uwagi: na podstawie zebranej dokumentacji archiwalnej oraz kwerendy prasowej nie udało się ustalić dokładnej daty powierzenia hieromnichowi Pimenowi funkcji przełożonego monasteru w Radecznicy oraz przeniesienia hieromnicha Antoniego z radecznickiego monasteru. Skrót w tabeli oraz wykresach: b. d. - brak danych.

21 Biogram na podst.: APL, ChZD, sygn. 1031, k. 20 v. - 21; APL, ChKG, sygn. 441, k. 285; Objawlenija i izwiestija, ChWJW, 7/1880, s. 103; Objawlenija i izwiestija, ChWJW, 7/1881, s. 51.
} 
z kijowskich monasterów. 5 grudnia 1865 r. odbyły się jego mnisze postrzyżyny z imieniem Hipacy. Święcenia diakońskie otrzymał 20 marca 1863 r., a kapłańskie 15 kwietnia 1875 r. Dwa lata później hieromnich Hipacy został przeniesiony do Domu Biskupiego w Warszawie (6 grudnia), a 28 lutego 1880 r. do Domu Biskupiego w Chełmie. Duchowny 22 stycznia 1881 r. otrzymał nagrodę cerkiewną - prawo noszenia nabiedrennika ${ }^{22}$. Zgodnie $\mathrm{z}$ rozporządzeniem władyki Modesta 15 stycznia 1882 r. hieromnich Hipacy został przełożonym domu zakonnego w Radecznicy, a od 12 kwietnia 1882 r. p. o. proboszcza. Realnie zaczął pełnić swoją funkcję po przekazaniu dokumentacji parafialnej przez ks. Antoniego Draczyńskiego ${ }^{23}$ - 27 kwietnia 1882 r. Nie udało się ustalić do kiedy dokładnie hieromnich Hipacy pełnił funkcję pierwszego przełożonego klasztoru w Radecznicy.

Od 21 września 1883 r. posługę przełożonego sprawował hieromnich Antoni (Dziuba). Arseniusz Dziuba ${ }^{24}$ urodził się w Kijowie w 1847 r. Życie monastyczne zaczął 14 grudnia 1868 r. wstępując do kijowskiego monasteru pw. św. Mikołaja Cudotwórcy. Nowicjat (cs. posłuszanije) kontynuował w monasterze pw. Św. Trójcy w Kijowie. W 1872 r. został przeniesiony do kijowskiego monasteru pw. św. Mikołaja. Tam 14 września 1878 r. otrzymał postrzyżyny mnisze z imieniem Antoni. Od 7 września 1882 r. przebywał w Chełmskim Domu Biskupim. Dzień później został wyświęcony na diakona, a 8 września 1883 r. wyświęcony na kapłana. 21 września 1883 r. hieromnich Antoni otrzymał nominację na przełożonego męskiego domu zakonnego w Radecznicy. Za służbę Cerkwi mnicha nagrodzono nabiedrennikiem (5 czerwca 1885 r.). Hieromnich Antoni był przełożonym monasteru do 16 września $1891 \mathrm{r}$.

Tego dnia nastąpiła zmiana w pełnieniu funkcji przełożonego w Radecznicy. Hieromnicha Antoniego zastąpił najbardziej znany radecznicki przełożony hieromnich Krzysztof (Sakowicz). Chryzant Sakowicz ${ }^{25}$ był synem ks. Jana Sakowicza niosącego posługę we wsi Swiatiec (diecezja wołyńska). Urodził się w 1833 r. Sześć lat później zmarła

\footnotetext{
22 Nabiedrennik (palica) - chusta w kształcie rombu z wyhaftowanym krzyżem symbolizuje miecz duchowy, czyli Słowo Boże (na podst.: K. Bondaruk, Nauka o prawosławnych nabożeństwach, Białystok 1987, s. 56).

23 Biogram ks. A. Draczyńskiego zob.: K. Latawiec, Parafia prawosławna we Włodawie w latach 1875 - 1915, [w:] Włodawa $i$ wieś nadbużańska w epoce nowożytnej, red. M. Bem, A. Duszyk, Radom - Włodawa 2007, s. 199 - 201.

24 Biogram na podst.: APL, ChZD, sygn. 1365, k. 1 - 4; APL, ChZD, sygn. 1031, k. 7 v. -8.

25 Biografia na podst.: APL, ChZD, sygn. 1705, b. p. (cały poszyt); APL, Chełmskie Bractwo Prawosławne (1879 - 1915; dalej ChBP), sygn. 12, k. 164 - 164 v.; PKLG na 1893 god, Ljublin 1892, s. 245; PKLG na 1895 god, Ljublin 1894, s. 252; Pamiat' pokojnago ijeromonacha Christofora, $w$ mire Sakowicza, ChWJW, 9/1897, s. 178 - 179; Pamiat' pokojnago ijeromonacha Christofora, w mire Sakowicza, „Warszawskij Dniewnik”, 100/1897, s. 4; Iz autobiograficzeskich wospominanii ijeromonacha Christofora (Sakowicza), „Chołmskaja Cerkownaja Żyzn”, 4/ 1909, s. 153 - 155; Duchownyje piesnopienija ijeromonacha Christofora, Chołm 1913, ss. 350; Krestnaja Piesn' ijeromonacha Christofora. Słowa i muzyka ijeromonach Christofor. Poczajew 1905, ss. 60 + 4.; W. Szajdickij, Sostaw lic służiwszich i służaszczych w seminarii (1875 - 1910), [w:] Sbornik statiej po istorii Chołmskoj Duchownoj Sieminarii. Po powodu stopiatidiesiatiletija suszczestwowanija sieminarii (1760-1910), Chołm 1910, s. 47 - 48.
}

matka chłopca - Daria Sakowicz z d. Sawłuczyńska. Między 1842 a 1849 r. uczył się w Szkole Duchownej w Krzemieńcu, naukę kontynuował w Wołyńskim Seminarium Duchownym w Krzemieńcu, które ukończył w 1855 r.. W III klasie seminarium Chryzant Sakowicz chciał zostać mnichem, w tym celu szukał odpowiedniego monasteru. Początkowo skierował się do Ławry Kijowsko-Pieczerskiej, gdzie rozpoczął nowicjat. Jego droga do monastycyzmu wiodła przez Woroneż, Zadońsk, Sarow i Ławrę pw. Świętej Trójcy i św. Sergiusza z Radoneża w Siergijew Posadzie niedaleko Moskwy. Podczas monastycznych poszukiwań zatrzymał się w wielodzietnej rodzinie, w której dzieci nie znały modlitwy „Ojcze Nasz”, co go zaskoczyło. Rodzice wytłumaczyli mu, że dzieci aby dojść do cerkwi musiały pokonać ponad 13 $\mathrm{km}$, a we wsi nie funkcjonowała szkoła cerkiewna. Zderzenie z rzeczywistością uświadomiło młodemu Sakowiczowi, iż należy wrócić do rodzinnej wsi i rozpocząć pracę pedagogiczną. Po powrocie do diecezji wołyńskiej był nauczycielem w szkole przy żeńskim monasterze w Horodyszczu (1864 - 1868) i szkole ludowej w Żukowsku (1868 - 1872) oraz sekretarzem w Bractwie pw. św. św. Cyryla i Metodego w Ostrogu (1872-1873). W 1873 r. został pedagogiem w szkole ludowej w Brykowce. Za namową hrabiny Antoniny Błudowej (1812 - 1891) postanowił pozostać bezżennym duchownym. Przyjął święcenia diakońskie, a 17 września 1879 r. - kapłańskie. Na celibat wpłynęło osobiste przeżycie - tuż przed zawarciem małżeństwa zmarła narzeczona ks. Chryzanta. Dzięki charyzmie i zaangażowaniu w pracę duszpasterską w parafii w Brykowce, ks. Sakowicz zwalczał powszechny alkoholizm i doprowadził do zapełnienia się świątyni wiernymi podczas nabożeństw. W trakcie służb cerkiewnych w brykowieckiej świątyni śpiewał nie chór, lecz wszyscy ludzie. Od młodości kapłan pisał wierszowane utwory paraliturgiczne i komponował do nich melodię. W Brykowce powstał pierwotny tekst pt. „Duchownyje piesnopienija". W zbiorze wierszy znalazły się fragmenty wydzielonej później oraz spopularyzowanej na terenie Północnego Podlasia, Wileńszczyzny i Grodzieńszczyzny „Krestnoj Piesni”"26. Za napisanie tej pierwszej w 1885 r. ks. Sakowicz otrzymał od Świętego Synodu Rosyjskiej Cerkwi Prawosławnej nagrodę - złoty krzyż. Za namową władz diecezjalnych zdecydował się wstąpić do Ławry pw. Zaśnięcia Bogurodzicy w Poczajowie. Efektowna praca duszpasterska przyczyniła się do tego, że parafianie z Brykowki odprowadzili swojego kapłana pieszo do Poczajowa. 19 grudnia 1886 r. ks. Chryzant (Sakowicz) w poczajowskim monaste-

\footnotetext{
Tekst popularyzujący wiedzę dotyczącą „Krestnoj Piesni” zob.: S. Dmitruk, Zapomniany autor „Krestnoj Piesni”, „Przegląd Prawosławny”, 3/2012. Do chwili obecnej rękopisy utworów i zapisów nutowych hieromnicha Krzysztofa (Sakowicza) nie zostały odnalezione w archiwach. Znalezienie jego rękopisów prawdopodobnie umożliwi analizę treści oraz ustalenie genezy i inspiracji do napisania „Krestnoj pieśni”. Do momentu odnalezienia w Bibliotece KUL w Lublinie jesienią 2011 r. Kriestnaja Piesn' ieromonacha Christofora... wśród wiernych i duchowieństwa prawosławnego w Polsce funkcjonował pogląd o greckokatolickim pochodzeniu utworów i naleciałości paraliturgicznej z czasów Unii Brzeskiej. „Krestnaja Piesn”' w dalszym ciągu wymaga naukowego opracowania, analizy treści oraz weryfikacji poglądów na temat utworów paraliturgicznych wykonywanych w Rosyjskiej i Polskiej Cerkwi Prawosławnej.
} 
rze otrzymał postrzyżyny mnisze z imieniem Krzysztof. 28 września 1887 r. został spowiednikiem w Chełmskim Seminarium Duchownym. Posługę niósł do września 1891 r., kiedy został przyjęty do Domu Biskupiego w Chełmie. Tam codziennie sprawował Liturgię, kierował chórem cerkiewnym oraz zajmował się pracą z dziećmi. 16 września 1891 r. hieromnich Krzysztof skierował na ręce bp. lubelskiego Flawiana (Gorodeckiego; 1885 - 1891) prośbę o przeniesienie z Chełmskiego Seminarium Duchownego (w latach 1886 - 1891 był spowiednikiem w seminarium) do monasteru pw. św. Antoniego Pieczerskiego w Radecznicy. W tym samym dniu hierarcha pozytywnie rozpatrzył prośbę mnicha. W Radecznicy hieromnich Krzysztof kontynuował pracę pedagogiczną z dziećmi - m. in. kierował szkołą dla 18 chłopców. Równolegle zajmował się twórczością literacką. To tutaj powstał ostateczny tekst „Krestnoj Piesni”. Świadczy o tym stwierdzenie hieromnicha Pimena w wydanych w 1913 r. „Duchownych piesnopienijach”: W przedsięwziętym wydaniu „Duchownyje piesnopienija” hieromnicha Krzysztofa, napisanych przez niego w Radecznickiej Pustyni św. Antoniego, uważam za swój obowiązek wskazać przyczy$n y$, które pobudziły mnie do tego czynu ${ }^{27}$. Warto zaznaczyć, że w Poczajowie przed 1896 r. ukazał się po raz pierwszy zbiór poezji paraliturgicznej pt. „Duchownyje piesnopienija" autorstwa hieromnicha Krzysztofa. Pracą u podstaw mnich zasłużył na szacunek wśród miejscowej ludności. Wierni nazywali go „świętym człowiekiem”. 11 lutego 1896 r. hieromnich Krzysztof zwrócił się po raz trzeci do bp. lubelskiego Gedeona (Pokrowskiego; 1892 - 1896) z prośbą o zwolnienie go $\mathrm{z}$ funkcji przełożonego monasteru i przekazanie obowiązków hieromnichowi Pimenowi. W raporcie hieromnich Krzysztof pisał: „Chorobliwa starość nie pozwala mi pełnić cerkiewnych, gospodarczych i kancelaryjnych obowiązów. Hieromnich Pimen jest człowiekiem młodym, silnym i z uporem trudzacym się dla dobra Monasteru, może wypetniać obowiązki ${ }^{\prime 28}$. Bp Gedeon odrzucił prośbę mnicha. Ostatnią Liturgię hieromnich Krzysztof celebrował 15 lutego 1897 r. Tego samego dnia, po udzieleniu błogosławieństwa na spożywanie posiłku, przełożony wspólnoty w Radecznicy osunął się z krzesła i zmarł. Pogrzeb hieromnicha Krzysztofa odbył się 18 lutego 1897 r. Celebrowało go trzech miejscowych proboszczów i hieromnich Pimen (Gorbunow). Mowę pogrzebową wygłosił ks. Tymoteusz Tracz - proboszcz parafii w Szczebrzeszynie. W wydarzeniu uczestniczyło ok. 300 osób. Grób hieromnicha Krzysztofa do dnia dzisiejszego znajduje się na terenie klasztoru bernardynów w Radecznicy.

Ostatnim przełożonym męskiego monasteru pw. św. Antoniego Pieczerskiego w Radecznicy był hieromnich Pimen (Gorbunow). Nie jest znana data powierzenia funkcji przełożonego hieromnichowi Pimenowi. Można się domyślić (zgodnie z cytowaną wcześniej korespondencją hieromnicha Krzysztofa), że nastąpiło to szybko, prawdopodobnie tuż po śmierci Sakowicza. Piotr Gorbunow ${ }^{29}$

\footnotetext{
Duchownyje piesnopienija..., s. 3

APL, ChBP, sygn. 12, k. $164 \mathrm{v}$.

APL, ChKP, sygn. 49, k. 2 v - 3 v.
}

urodził się w 1859 r., ukończył wiejską szkołę. W sierpniu 1883 r. został psalmistą w cerkwi pw. Podwyższenia Krzyża Świętego w Wołyńskim Domu Biskupim. 10 sierpnia 1887 r. abp wołyński Palladiusz (Hankiewicz; ur. 1823, zm. 1893) udzielił mu postrzyżyn mniszych $z$ imieniem Pimen. Władyka Palladiusz 20 września 1887 r. wyświęcił go na hierodiakona i skierował do monasteru pw. św. Onufrego, położonego na terenie diecezji kijowskiej, dwa lata później przeniesiony do Radecznicy. W 1890 r. bp lubelski Gedeon wyświęcił go na hieromnicha. 27 września 1898 r. hieromnich Pimen został przeniesiony do diecezji aleuckiej i północnoamerykańskiej, którą kierował wówczas bp Tichon (Bielawin; ur. 1865, zm. 1925). Na przestrzeni dwóch lat służył w cerkwiach: Charterburgu i Charleroi. W 1902 r. został przeniesiony $\mathrm{z}$ diecezji północnoamerykańskiej i udał się do Staro-Charkowskiego monasteru pw. Przemienienia Pańskiego. Dalsze losy mnicha nie są znane.

Oprócz czterech hieromnichów, pełniących funkcję przełożonego męskiego domu zakonnego w Radecznicy, posługę kapłańską nieśli trzej inni hieromnisi - Innocenty (Tryszczuk), Onufry (Skibiński) i nieznany z nazwiska Doroteusz. Na temat ostatniego wymienionego mnicha niewiele można wywnioskować ze szczątkowo zachowanych źródeł. Poza informacją, że 15 sierpnia 1890 r. został skierowany do Radecznicy i figurował w spisie mnichów na ten rok, nie udało się pozyskać dodatkowych wiadomości na jego temat ${ }^{30}$. Trochę więcej informacji mamy o dwóch pozostałych mnichach. Antoni Skibiński ${ }^{31}$ urodził się w Chełmie w 1857 r. Ukończył Chełmskie Seminarium Duchowne. Skibiński w 1878 r. był psalmistą w jednej z cerkwi dekanatu zamojskiego, a w kolejnych latach w dekanacie włodawskim. 19 marca 1885 r. rozpoczął nowicjat (cs. posłuszanije) w Chełmskim Domu Biskupim. 31 marca 1885 r. został wyświęcony na diakona, a 6 sierpnia 1887 r. na kapłana. W 1890 r. niósł posługę hieromnicha w męskim domu zakonnym w Radecznicy. Pełnił funkcję proboszcza, od 1895 r. do co najmniej 1910 r., w parafii Czekanów (dekanat siedlecki). 25 sierpnia 1868 r. przyszły mnich Innocenty (Tryszczuk) ${ }^{32}$ rozpoczął nowicjat w kijowskim monasterze pw. Świętej Trójcy. W 1878 r. (15 sierpnia) został przyjęty do grona braci Ławry Kijowsko-Pieczerskiej, a 1 sierpnia 1879 r. Domu Biskupiego w Chełmie, gdzie niósł posługę prosfornika. 9 marca 1880 r. przyjął postrzyżyny mnisze z imieniem Innocenty, 20 sierpnia 1880 r. bp. lubelski Modest wyświęcił go na diakona, a 13 kwietnia $1881 \mathrm{r}$. na kapłana. 15 stycznia 1883 r. został przeniesiony do męskiego domu zakonnego w Radecznicy. Siedem lat później powrócił do Chełmskiego Domu Biskupiego. Dalsze losy mnicha nie są znane.

\footnotetext{
30 PKLG na 1890 god, Lublin 1890, s. 240.

31 APL, ChZD, 1365, k. 4 v. - 5; PKLG na 1890 god, Lublin 1890, s. 240; G. Sosna, A. Troc-Sosna, Hierarchia i kler..., s. 634; J. Fedoryk, Duchowieństwo prawosławne w Królestwie Polskim w latach 1875 1905, Lublin 2010, s. 255 (wydruk komputerowy rozprawy doktorskiej w Bibliotece Uniwersytetu Marii Curie-Skłodowskiej w Lublinie).

32 APL, ChWDKP, sygn. 239, k. 1 - 2; APL, ChZD, sygn. 1365, k. 15 - 16; APL, ChZD, sygn. 1031, k. 19 v. - 21, k. 28 v. - 31; G. Sosna, A. TrocSosna, Hierarchia $i$ kler..., s. 309; K. Latawiec, W stużbie imperium..., s. 222.
} 
W radecznickim męskim domu zakonnym służyli dwaj hierodiakoni - Antoni (Miroszniczenko) i Serapion (Milniewicz). Kondrat Miroszniczenko ${ }^{33}$ urodził się 21 września 1852 r. we wsi Nikolska w guberni charkowskiej. Był synem Marty i Mikołaja Mirszniczenko. 9 maja 1866 r. został przyjęty do monasteru pw. Św. Trójcy w Kijowie, a 23 marca 1869 r. zaliczono go w poczet nowicjuszy tego klasztoru. W 1876 r. został przeniesiony do Ławry Kijowsko - Pieczerskiej. W kijowskim monasterze bardzo dobrze zapoznał się ze śpiewem cerkiewnym, ponieważ niósł posługę w ramach chóru monasterskiego. 3 maja 1882 r. nowicjusza przeniesiono z Lawry Kijowko - Pieczerskiej do radecznickiej filii Chełmskiego Domu Biskupiego. 5 maja 1882 r. bp lubelski Modest postrzygł go w małą schimę z imieniem Antoni, a 13 czerwca udzielił święceń diakońskich. Hieromnich Antoni pełnił funkcję diakona biskupiego, a między 1 lipca 1882 r. do 20 kwietnia 1885 r. był ekonomem Chełmskiego Domu Biskupiego, 9 października 1885 r. został ponownie włączony do wspólnoty klasztornej Ławry Kijowsko - Pieczerskiej. Stefan Milniewicz ${ }^{34}$ urodził się w 1846 r. Ukończył szkołę cerkiewną na terenie guberni wołyńskiej. 24 marca 1872 r. wstąpił do monasteru w Poczajowie. 22 lutego 1875 r. został przeniesiony do monasteru pw. Podwyższenia Krzyża Świętego w Dubnie, a 12 czerwca 1877 r. do monasteru w Zahajcach. Po powrocie do Poczajowa, od 7 marca 1879 r. do 15 stycznia 1884 r., był psalmistą w jednej z monasterskich cerkwi. 14 października 1886 r. został postrzyżony z imieniem Serapion. Od 7 marca 1888 r. niósł posługę w monasterze w Żyrowicach (diecezja litewska). Został wyświęcony na diakona 5 lutego 1889 r. Nie wiadomo kiedy hierodiakon Serapion trafił do Jabłecznej. 18 stycznia 1893 r. mnicha przeniesiono do domu zakonnego w Radecznicy. Od końca 1895 r. hierodiakon Serapion służył w diecezji wołyńskiej.

Prawdopodobnie jedynym mnichem bez święceń diakońskich i kapłańskich był Antoni (Jaroszuk). Jedyną wzmianką na jego temat jest poniższa informacja zamieszczona w "ChWJW"35: 1 kwietnia 1897 r. ówczesny archimandryta Tichon (Bieławin) dokonał postrzyżyn mniszych Romana Jaroszuka - nowicjusza męskiego domu zakonnego w Radecznicy - z imieniem Antoni. Nie udało się odnaleźć informacji, które wyjaśniłyby od kiedy Roman Jaroszuk niósł nowicjat w Radecznicy oraz uszczegóławiały biogram mnicha Antoniego.

Czterej nowicjusze męskiej radecznickiej wspólnoty monastycznej to: Antoni (Łukaszewicz), Cyprian (Jankowski), Piotr (Bystrymowicz) i Mikołaj (Simoniuk). Dwaj pierwsi rozpoczęli nowicjat w Radecznicy w grudniu 1885 r., zaś dwaj kolejni w 1886 r. i w 1887 r. Za wyjątkiem Piotra (Bystrymowicza) na temat pozostałych nowicjuszy udało się odnaleźć jedynie wzmianki. Antoni Łukaszewicz ${ }^{36}$ był synem psalmisty w Browszczy położonej na terenie guberni wołyńskiej. 2 grudnia 1885 r. wstąpił do domu za-

\footnotetext{
Biografia na podst.: APL, ChWDKP, sygn. 306 (cały poszyt); APL, ChWDKP, sygn. 457, k. 4 v. -5.

34 APL, ChZD, sygn. 1905, k. 1 - 3 v.

35 Jeparchialnyje rasporażnija i izwiestija, ChWJW, 7/1897, s. 119.

36 APL, ChZD, sygn. 1365, k. 5.
}

konnego w Radecznicy celem odbycia nowicjatu. Cyprian Janowski ${ }^{37}$ urodził się w $1866 \mathrm{r}$. Jego ojciec był duchownym $\mathrm{w}$ dekanacie jaworowskim na terenie Galicji. 20 grudnia 1885 r. Cyprian rozpoczął nowicjat w Radecznicy. Mikołaj Simoniuk ${ }^{38}$ urodził się w 1867 r. w guberni siedleckiej. 20 kwietnia 1887 r. wstąpił do domu zakonnego w Radecznicy. Piotr Bystrymowicz ${ }^{39}$ urodził się 24 sierpnia $1867 \mathrm{r}$. w Grodnie w rodzinie mieszczańskiej. Jego ojcem był Grzegorz Bystrymowicz. Został ochrzczony w grodzieńskiej cerkwi pw. Mądrości Bożej. W latach 1879 - 1883 uczęszczał do Warszawskiej Szkoły Duchownej. Między 20 sierpnia 1885 r. a 23 września 1886 r. odbył nowicjat w monasterze pw. św. Onufrego Wielkiego w Jabłecznej. 7 października 1886 r. nowicjusz Piotr poprosił bp. lubelskiego Flawiana o przeniesienie z monasteru jabłeczyńskiego do Radecznicy. Prawdopodobnie pod koniec $1887 \mathrm{r}^{40} \mathrm{z}$ nieznanych powodów zrezygnował z nowicjatu. Od 13 stycznia $1888 \mathrm{r}$. był psalmistą w parafii Korczówka w I dekanacie bialskim, później w Kosteniewiczach (I dekanat bialski), od 1 października 1897 r. w Wojsławicach. Funkcję psalmisty w parafii Pniówno w I dekanacie chełmskim objął 1 września 1903 r. Jego dalsze losy nie są znane.

Analizowane biogramy umożliwiają, w mniejszym lub większym stopniu, wyciągnięcie wniosków badawczych związanych z domem zakonnym w Radecznicy. Należy zgodzić się z twierdzeniem K. Latawca dotyczącym pochodzenia (zob. Wykres 1. Mnisi w Radecznicy [lata 1882-1899] wedlug miejsca urodzenia ${ }^{41}$ ) większości mnichów z terenów guberni wołyńskiej (21 \%) i kijowskiej $(30 \%)^{42}$.

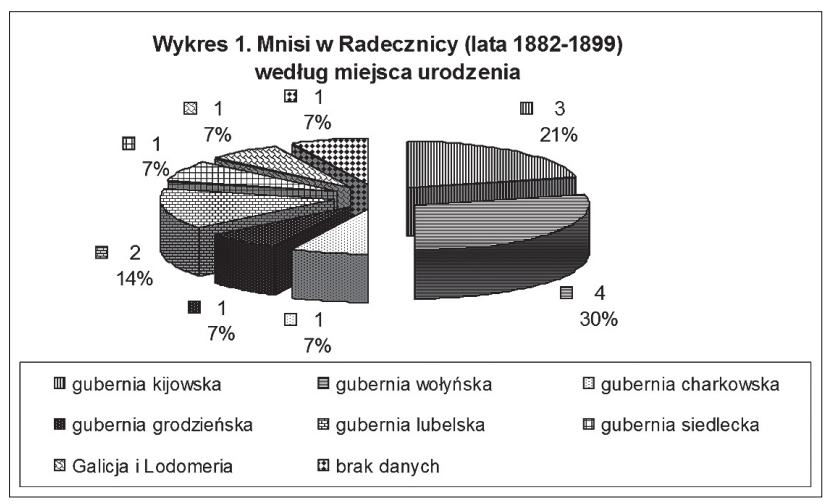

Dwie osoby pochodziły z guberni grodzieńskiej i charkowskiej. K. Latawiec konstatuje: „Zadaniem klasztoru męskiego w Radecznicy było oddziaływanie misyjne na ludność pounicka. Zadanie to, nałożone na te placówkę, było realizowane przez przyjmowanie $w$ charakterze nowicjuszy osób spośród miejscowej społeczności wiejskiej wyznania prawosławnego" ${ }^{\text {"43 }}$. Wydaje się, że nie do końca skutecznie była prowadzona misja wśród miejscowej ludności. Zaledwie 3

\footnotetext{
37 Tamże, k. 5 v.

38 Tamże, sygn. 1365, k. 5.

39 Biogram na podst.: APL, ChZD, sygn. 1258, k. 1 - 10; K. Latawiec, W stużbie imperium..., s. 222; G. Sosna, A. Troc-Sosna, Hierarchia i kler..., s. 151.

40 Wnioskowanie na podstawie dalszej części biogramu.

41 Wykres 1. na podstawie sporządzonych wyżej biogramów.

42 K. Latawiec, $W$ stużbie imperium..., s. 223.

43 Tamże.
} 
osoby $(21,43 \%)$ pochodziły z terenu guberni lubelskiej i siedleckiej. O ile pochodzący z Grodzieńszczyzny Piotr (Bystrymowicz) był związany z Warszawą i nauką w lokalnej szkole cerkiewnej, o tyle nie można jednoznacznie wytłumaczyć powołania Cypriana (Jankowskiego), który trafił do radecznickiej wspólnoty z Galicji. Nierozstrzygniętą kwestią pozostają powody przybycia wymienionego nowicjusza do Radecznicy: czy był to wpływ napływowego do diecezji chełmsko-warszawskiej duchowieństwa pochodzącego z Galicji ${ }^{44}$, czy ośrodek monastyczny w Radecznicy położony relatywnie blisko granicy z Austro-Węgrami mógł oddziaływać na ludność ruską w Galicji. Wydaje się, że pierwsza hipoteza jest bardziej realna. Mogłyby ją potwierdzić jedynie nieodnalezione do dzisiaj źródła. Odpowiedź na pytanie dlaczego były tak nikłe powołania mężczyzn do domu zakonnego w Radecznicy nie znajduje odbicia w źródłach. Wiadomo, że nieefektowna i nieefektywna praca misyjna stała się przyczyną przekształcenia męskiego monastycyzmu w żeński. Przeanalizowanie pochodzenia geograficznego uniemożliwia jednoznaczne wnioskowanie na temat narodowości badanych osób. Wydaje się, że jedynie hierodiakona Antoniego (Mironiszczenko) pochodzącego z guberni charkowskiej, można nazwać Rosjaninem. Hieromnich Krzysztof (Sakowicz) tworzył poezję w języku rosyjskim, ale pochodzenie (Wołyń) oraz powszechne uznanie wśród ludności zamieszkującej okolice Radecznicy, pozwalają wątpić w przypisanie mu narodowości rosyjskiej. Misyjny charakter ośrodka zakonnego, funkcjonowanie w społeczności rzymsko-katolickiej i polskojęzycznej, mała liczba wiernych, skomplikowana sytuacja wyznaniowa i narodowościowa po kasacie unii brzeskiej ${ }^{45}$ a także przeanalizowane pochodzenie geograficzne, wskazują na pozyskiwanie do męskiego domu w Radecznicy osób, które posługiwały się językiem ukraińskim. Taki zabieg umożliwiłby lepsze możliwości misyjne. Czy tak było? Czy wśród mnichów pochodzących z Kijowszczyzny, Wołynia i Galicji ukształtowała się ukraińska, względnie ruska, świadomość narodowa bądź etniczna? Te pytania pozostają bez odpowiedzi.

\footnotetext{
${ }_{44}$ Więcej o prawosławnym duchowieństwie posługującym na terenie diecezji chełmsko-warszawskiej pochodzącym z Galicji zob. m. in.: J. Lewandowski, Na pograniczu. Polityka władz państwowych wobec unitów Podlasia i Chetmszczyzny. 1772 - 1875, Lublin 1996, s. 102; W. Osadczy, Święta Ruś. Rozwój $i$ oddziaływanie idei prawosławia w Galicji, Lublin 2007, s. 212 - 219; J. Fedoryk, Duchowieństwo prawosławne..., s. 23 - 24. 45 Szerzej zob. raport na temat sytuacji wyznaniowej $\mathrm{w}$ guberni lubelskiej i siedleckiej w 1880 r. (APL, ChBP, sygn. 1, k. 29 - 46). Wśród raportów znalazło się sprawozdanie dziekana I dekanatu tomaszowskiego - ks. Korneliusza Gierasimowicza. Duchowny pisał bp lubelskiemu Modestowi (Strelbickiemu) o tym, że lokalni misjonarze, którzy mają docelowo funkcjonować $\mathrm{w}$ diecezji chełmsko-warszawskiej powinni posługiwać się „miejscowym językiem” (czyli ukraińskim; tamże, k. 44 v.). Analizowany raport umożliwia wysunięcie tezy, iż do domu zakonnego w Radecznicy mogli być sprowadzani mnisi znający język ukraiński. Dodatkowym argumentem przemawiającym za tą tezą była postawa długoletniego (lata 1878 - 1911) proboszcza parafii w Szczebrzeszynie ks. Tymoteusza Tracza. Duchowny ze Szczebrzeszyna wygłaszał kazania w języku ukraińskim. Homilie ks. Tracza zostały po latach docenione przez ówczesnego bp lubelskiego Eulogiusza (Gieorgijewskiego) [zob. J. Fedoryk, Duchowieństwo prawosławne..., s. 64, s. 110].
}

Oprócz pochodzenia geograficznego mnichów należy przyjrzeć się pochodzeniu społecznemu. Jest to zadanie trudne do oceny i niemiarodajne, ponieważ w 7 przypadkach (50 \% badanej społeczności) nie udało się ustalić stanu społecznego mnichów. Czterech wywodziło się z mieszczaństwa $(28,57 \%)$, dwóch miało pochodzenie chłopskie (14, $28 \%$ ), zaś hieromnich Krzysztof (Sakowicz) to potomek duchownego (7, $14 \%)$. Dane sugerują na znaczny odsetek pochodzenia mieszczańskiego wśród zamieszkałych w Radecznicy mnichów. Postawioną hipotezę potwierdzityby pełne dane źródłowe.

Bardziej zdekompletowane informacje dotyczą wykształcenia mnichów. W dziewięciu przypadkach (64, 3\%) nie posiadamy danych o otrzymanej edukacji. Szkoły cerkiewne w diecezji wołyńskiej ukończyły trzy osoby (21, 43\%), zaś Chełmskie Seminarium Duchowne i Warszawską Szkołę Cerkiewną odpowiednio jedna osoba (po 7, 14 \%). Brak danych uniemożliwia interpretację przedstawionej statystyki.

Badanie potwierdziło stwierdzenie K. Latawca dotyczące zdobycia doświadczenia w życiu klasztornym przez mnichów pełniących główne funkcje w Radecznicy ${ }^{46}$. W przypadku hieromnicha Doroteusza $(7,14 \%)$ nie udało się ustalić jaka była jego przeszłość monastyczna. Cztery osoby rozpoczynały duchowe zmagania w radecznickim domu zakonnym (28, 57 \%). Dla dwóch osób Radecznica była drugim miejscem pobytu (14, $29 \%$ ). Pozostała grupa mnichów (50 \%) niosła posługę w monasterach kijowskich (Ławra Kijowsko-Pieczerska, św. Mikołaja Cudotwórcy, Św. Trójcy, św. Onufrego), wołyńskich (Poczajów, Dubno, Zahajce), białoruskich (Żyrowice), rosyjskich (Radoneż, Sarow, Zadońsk), domach biskupich (Chełm, Warszawa, Poczajów) oraz w Jabłecznej. Sześciu mnichów posiadało ponad 14-letni (hierodiakon Serapion przebywał 21 lat $\mathrm{w}$ różnych monasterach) staż $\mathrm{w}$ zmaganiach monastycznych (42, $86 \%)$, trzej mnisi przebywali powyżej roku w monasterze w momencie przybycia do Radecznicy $(21,43 \%)$, dwaj rozpoczynali życie mnisze w opisywanym męskim domu zakonnym $(14,28 \%)$, a o trzech nie posiadamy informacji (21, $43 \%)$. Nie wiadomo w jaki sposób zdobyte $\mathrm{w}$ innych klasztorach doświadczenie przekładało się na pobyt mnichów w Radecznicy. Badanie dotyczące pobytu poszczególnych mnichów w samym domu zakonnym pw. św. Antoniego Pieczerskiego nie jest reprezentatywne ze względu na krótki okres funkcjonowania męskiego monastycyzmu w Radecznicy (realnie 17 lat) oraz fakt, iż w przypadku 6 osób (42, 86 \%) nie udało się ustalić długości pobytu. W przypadku pozostałych 8 osób (57, 14 $\%)$ : trzy $(21,43 \%)$ zdobyły dwuletnie lub roczne doświadczenie monastyczne, zaś pozostała piątka $(35,71 \%)$ ponad 5 lat poświęciła zmaganiom duchowym w Radecznicy. Najdłużej, 10 lat, w radecznickim domu zakonnym przebywał ostatni przełożony - hieromnich Pimen (Gorbunow).

Warto zastanowić się nad pytaniami: ile lat mieli poszczególni mnisi oraz czy była to wspólnota perspektywiczna dla rozwoju prawosławnego męskiego monastycyzmu.

46 K. Latawiec, W stużbie imperium..., s. 222 - 223. 
Próba badawcza nie jest kompletna, ponieważ podobnie jak $\mathrm{w}$ analizach przeprowadzonych wyżej nie mamy danych dotyczących czterech osób. Wykres 2 Wiek mnicha $w$ momencie przybycia do domu zakonnego $w$ Radecznicy (lata 1881 - 1899) oraz wykres 3 (Przedział wiekowy mnichów w latach 1881 - 1899 w momencie przybycia do domu zakonnego $w$ Radecznicy) ${ }^{47}$, oprócz analizy wieku, umożliwia obserwację tendencji związanej z perspektywą rozwoju życia monastycznego.
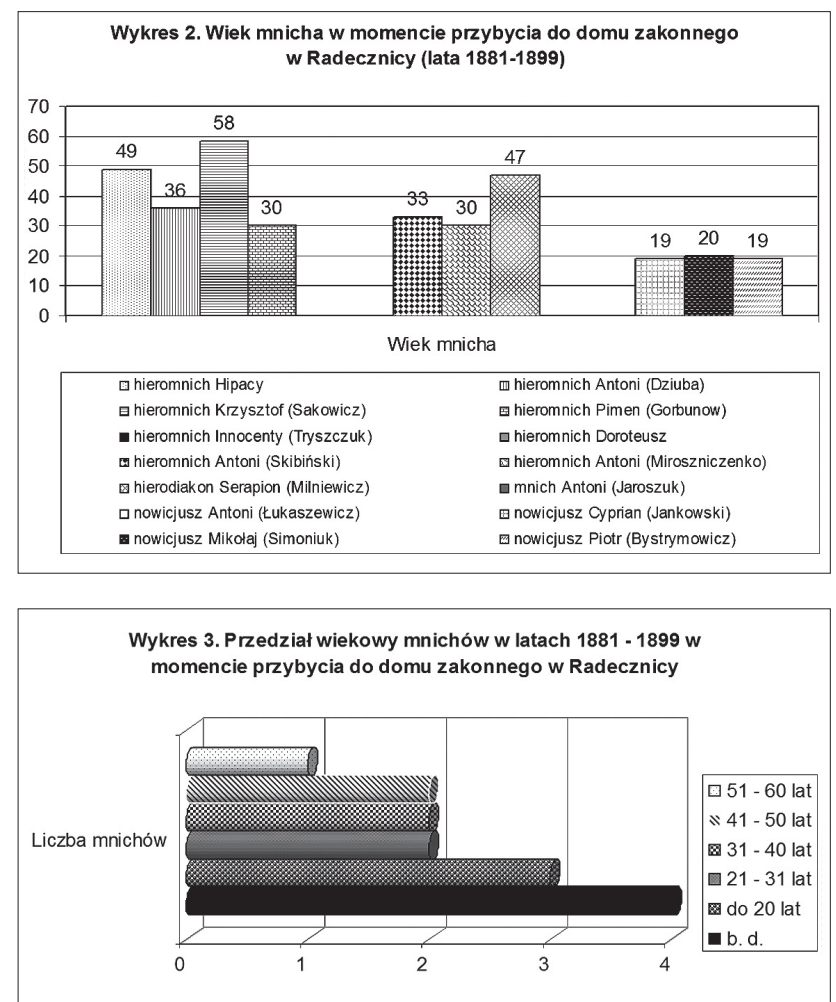

Średni wiek mnichów przybywających do Radecznicy wynosił ok. 34, 1 lat. Siedmiu znajdowało się w przedziale do 40 lat, zaś trzech miało powyżej 40 lat. W pierwszym przedziale wiekowym znajdowało się trzech nowicjuszy. Na tej podstawie można wysunąć tezę, że wspólnota

47 Wykresy 2 i 3 na podstawie opracowanych wyżej biogramów. monastyczna skupiona w domu zakonnym w Radecznicy miała perspektywę rozwoju. Mnisi szansy nie wykorzystali. Kwestią niepotwierdzoną w źródłach pozostaje pytanie dlaczego męski życie monastyczne, w przeciwieństwie do żeńskiego, nie było kontynuowane po 1899 r. Dość enigmatycznym pozostaje tłumaczenie hieromnicha Pimena przed władzami diecezji chełmsko-warszawskiej w październiku 1898 r. związane $z$ nierentownością monasteru ${ }^{48}$. Wydaje się, że na zmianę statusu życia monastycznego w omawianym domu zakonnym wpłynęły dość słabe efekty pracy misyjnej w rejonie Radecznicy. Należy przypomnieć, że był to podstawowy priorytet powołanego do życia w końcu 1881 r. monasteru.

Ostatnim elementem, na który warto zwrócić uwagę są imiona osób niosących posługę mniszą. Spośród czternastu mnichów, czterech (28, 57 \%) nosiło imię Antoni. Może to świadczyć o szerzeniu kultu i popularności imienia ku czci św. Antoniego Pieczerskiego. Z drugiej strony należy pamiętać, że Rosyjska Cerkiew Prawosławna dążyła w rejonie Radecznicy do zastąpienia kultu św. Antoniego z Padwy (patron skasowanego w 1864 r. zakonu bernardynów w Radecznicy $^{49}$ ) kultem św. Antoniego Pieczerskiego ${ }^{50}$.

Materiały źródłowe, prasa cerkiewna oraz literatura przedmiotu umożliwiły przeprowadzenie szerokiej analizy związanej z biografiami mnichów, którzy mieszkali w męskim domu zakonnym w Radecznicy między 1881 a 1899 r. Mimo zdekompletowanej dokumentacji udało się uzupełnić stan wiedzy związany z prawosławnym życiem monastycznym w Królestwie Polskim w końcu XIX w. Mankamentem badawczym pozostaje brak informacji na temat dyscypliny cerkiewnej omawianych osób. Opisane zagadnienie $\mathrm{w}$ dalszym ciągu wymaga uzupełnienia, dalszej analizy badawczej oraz porównania przedstawionych wniosków $\mathrm{z}$ badaniami na temat innych ośrodków monastycznych (Jabłeczna, monastery na Wołyniu, Grodzieńszczyźnie).

\footnotetext{
48 APL, ChGK, sygn. 441, k. 340 i 347.

49 Więcej na temat okoliczności kasaty zob.: S. Dmitruk, Żeńskie monastery..., s. 75 .

s0 Tamże, s. 46.
}

\section{Bibliografia}

\section{ŹRÓDŁA ARCHIWALNE}

Archiwum Państwowe w Lublinie:

Chełmskie Bractwo Prawosławne (1879 - 1915): sygn. 1; sygn. 12

Chełmski Konsystorz Greckokatolicki [1525-1595] 1596-1875 [1876-1905]: sygn. 441

Chełmski Konsystorz Prawosławny (1905 - 1918): sygn. 49

Chełmsko-Warszawski Duchowny Konsystorz Prawosławny (1875 - 1905): sygn. 239; sygn. 297; sygn. 306; sygn. 457

Chełmski Zarząd Duchowny ([1848] 1875-1905): sygn. 1031; sygn. 1258; sygn. 1365; sygn. 1705; sygn. 1905

Chełmski Zarząd Duchowny - „Klirowyje Wiedomosti” ([1848] 1875-1905): sygn. 1010

\section{PRASA}

„Chołmskaja Cerkownaja Żyzn” (1909)

„Chołmsko-Warszawski Jeparchialny Wiestnik” (1880; 1881; $1885 ; 1897 ; 1899)$

„Pamiatnaja Kniżka Lublinskoj Gubierni” (na 1887 god; na 1888 god; na 1890 god; na 1893 god; na 1895 god)

„Warszawskij Dniewnik” (1897).

\section{OPRACOWANIA}

Bondaruk K., Nauka o prawosławnych nabożeństwach, Białystok 1987. Dmitruk S, Zapomniany autor „Krestnoj Piesni”, „Przegląd Prawosławny", 3/2012. 
Dmitruk S., Żeńskie monastery prawosławne na terenie Królestwa Polskiego na przełomie XIX i XX w., „Teka Komisji Historycznej. Oddział PAN w Lublinie”, t. VI, Lublin 2009.

Duchownyje piesnopienija ijeromonacha Christofora, Chołm 1913.

Dzieje gminy Radecznica, red. R. Smoter-Grześkiewicz, Zamość 2006.

Fedoryk J., Duchowieństwo prawosławne w Królestwie Polskim w latach 1875 - 1905, Lublin 2010 (wydruk komputerowy rozprawy doktorskiej w Bibliotece Uniwersytetu Marii CurieSkłodowskiej w Lublinie).

Krestnaja Piesn' ijeromonacha Christofora. Słowa i muzyka ijeromonach Christofor. Poczajew 1905.

Latawiec K., Parafia prawosławna we Włodawie w latach 18751915, [w:] Włodawa i wieś nadbużańska w epoce nowożytnej, red. M. Bem, A. Duszyk, Radom - Włodawa 2007.

Latawiec K., W stużbie imperium...Struktura społeczno-zawodowa ludności rosyjskiej na terenie guberni rosyjskiej w latach 18641915, Lublin 2007.
Lewandowski J., Na pograniczu. Polityka władz państwowych wobec unitów Podlasia i Chelmszczyzny. 1772-1875, Lublin 1996.

Osadczy W., Święta Ruś. Rozwój i oddziaływanie idei prawosławia w Galicji, Lublin 2007.

Pawluczuk U., Ośrodki monastyczne w XIX w. na terenach Rzeczypospolitej, [w:] „Pokazanie Cerkwie prawdziwej...”. Studia nad dziejami i kultura Kościoła prawosławnego w Rzeczypospolitej, Białystok 2004.

Pawluczuk Urszula, Życie monastyczne w II Rzeczypospolitej, Białystok 2007.

Rapa S., Ośrodek kultu religijnego w Radecznicy w latach 17721914, [w:] Radecznica. Ośrodek życia religijnego i społecznokulturalnego, red. R. Jusiak, Kalwaria Zebrzydowska 2006.

Sosna G., Troc-Sosna A., Hierarchia i kler Kościoła Prawosławnego w granicach II Rzeczypospolitej i Polski powojennej w XIX XXI wieku, Ryboły 2012.

Szajdickij W., Sostaw lic służiwszich i służaszczych $w$ seminarii (1875-1910), [w:] Sbornik statiej po istorii Cholmskoj Duchownoj Sieminarii. Po powodu stopiatidiesiatiletija suszczestwowanija sieminarii (1760-1910), Chołm 1910.

Rozmiar artykułu 1,1 arkusza wydawniczego 